\title{
KODE ETIK AKUNTAN PUBLIK DALAM KAIDAH FIKIH MUAMALAH
}

\author{
PUBLIC ACCOUNTING CODE OF ETHICS IN THE FIQIH MUAMALAH RULES
}

\author{
Astuti Dola Bastina ${ }^{1)}$, Tjiptohadi Sawarjuwono ${ }^{2)}$, Gemelthree Ardiatus Subekti ${ }^{3)}$ \\ Universitas Airlangga
}

\begin{abstract}
This study aims to contribute to determining decisions in an ethical dilemma of an auditor by the rules of fiqh muamalah. The principles of fiqh discussed in this article are the intention of all the charity requirements of an auditor, the intermediary law is the same as the auditor's objective law, the law of origin is lawful, unless there is a proposition that prohibits it, and the law prioritizes rejecting mafsadat rather than taking benefits. The approach in the formulation of this thought uses a literature study by comparing Islamic figures who apply the muamalah fiqh rules in their daily lives with the case of auditors who have not applied muamalah figh rules in their work and focus on primary literature. This study proposes the principles of muamalah figh to address the auditor's ethical dilemma. The essence of ethical matters is very important in accounting, especially in the context of developing and enhancing the role of the accounting profession to be able to act professionally.
\end{abstract}

Keywords: Auditing, Ethics, Fiqh, Standard

\begin{abstract}
ABSTRAK
Penelitian ini bertujuan mampu memberikan kontribusi untuk menentukan keputusan dalam dilema etis seorang auditor yang sesuai dengan kaidah-kaidah fikih muamalah. Kaidah-kaidah fikih yang dibahas dalam artikel ini adalah niat syarat seluruh amal seorang auditor, hukum perantara sama dengan hukum tujuan seorang auditor, hukum asal muamalah adalah halal, kecuali ada dalil yang melarang, serta hukum mendahulukan menolak mafsadat daripada mengambil manfaat. Pendekatan dalam perumusan pemikiran ini menggunakan studi kepustakaan dengan membandingkan antara tokoh Islam yang menerapkan kaidah fikih muamalah dalam kehidupan sehari-harinya dengan kasus auditor yang kurang menerapkan kaidah fikih muamalah dalam pekerjaannya dan berfokus pada literatur primer. Penelitian ini mengusulkan kaidah-kaidah fikih muamalah untuk mengatasi permasalahan dilema etis auditor. Esensi perihal etis sangat penting dalam akuntansi terutama dalam rangka pengembangan dan peningkatan peran profesi akuntan untuk dapat bertindak secara profesional.
\end{abstract}

Kata Kunci: Audit, Etika, Fikih, Standar.

Corresponding author :

Email : Adbastina93@gmail.com ${ }^{\mathbf{1}}$, tjiptohadi@feb.unair.ac.id ${ }^{2)}$, gemel3as@gmail.com ${ }^{3}$

DOI : https://doi.org/10.33369/j.akuntansi.9.3.171-184 


\section{PENDAHULUAN}

Profesi auditor merupakan profesi yang membutuhkan kepercayaan atas kualitas informasi yang dihasilkan yang diberikan kepada klien (Singgih dan Bawono, 2010). Auditor haru mempunyai keahlian yang mumpuni terkait profesionalisme, pengetahuan dalam mendeteksi kekeliruan, kemampuan menjaga etika profesi (Herawaty dan Susanto, 2010), serta kualitas auditnya (Alim et al., 2007). Untuk memenuhi kebutuhannya auditor dituntut mematuhi kode etik, yaitu kesadaran berperilaku etis (Futri dan Juliarsa, 2014). Namun, auditor selalu dihadapkan dengan dilema etika sewaktu berhadapan dengan pilihan antara nilai-nilai yang dipegang oleh auditor dan yang ada dalam suatu tatanan social dan waktu tertentu. Hal ini terjadi dalam menghadapi situasi konflik tentang manajemen laba, operasi perusahaan atau kinerja yang tergambar dengan data yang lebih tinggi dengan maksud untuk mendapatkan penghargaan (Tjun et al., 2013).

Dalam melakukan audit, biasanya auditor merasakan dilema etis saat mendapat intervensi dari satuan kerja, selain itu ketika auditor dihadapkan dengan klien yang merupakan seorang teman akan mengalami perasaan tidak enak hati saat melaporkan kesalahannya. Selain itu, dilemma yang dirasakan auditor saat harus menghadapi persepsi publik, dimana auditor dianggap tidak dapat memberikan hasil yang maksimal ketika melakukan audit, semisal adanya persepsi bahwa auditor bisa disuap, lemah dan persepsi negatif lainnya. Auditor merasa kecewa ketika terdapat intervensi yang dapat mempengaruhi opini audit (Noviriani, Ludigdo, \& Baridwan, 2018).

Dalam situasi konflik, klien selalu berupaya dan mencoba melakukan tekanan-tekanan terhadap auditor dengan memakasakan opini yang mungkin tidak sesuai atau melanggar etika. Jika auditor memenuhi segala keinginan klien berarti auditor terindikasi melakukan pelanggaran standar professional, sedangkan jika menolak keinginan klien maka akan berdampak pemberian sanksi klien seperti kemungkinan penghentian penugasan (Nichols dan Price, 1976). Dilemma auditor saat termotivasi menunjukkan kepatuhan terhadap etika profesi dan standar audit, sehingga auditor akan mengalami gejolak yaitu konflik audit (Khoriyah, 2013). Menurut teori konflik, keberadaan konflik audit memungkinkan untuk memicu suatu dilema etis bagi auditor (Tsui dan Gul, 1996).

Tekanan dapat memengaruhi keindependenan yang ditimbulkan dari konflik kepentingan antara auditor dan organisasi kliennya (manajemen dan pemegang saham) dikarenakan kebenaran laporan audit yang mungkin tidak terlihat dalam kepentingan entah itu di pihak manajemen atau pemegang saham atau kedua kelompok tersebut, konflik antara tugas profesional auditor dan kepentingan diri, konflik antara manajer dan pemegang saham, serta konflik antara organisasi klien dan orang ketiga. Ketika dikaitkan kepada syariat, konflik-konflik tersebut merupakan contoh dari konflik muamalah. Menurut Noviriani et al., (2018) ada beberapa kesadaran yang harus dimiliki oleh seorang auditor, salah satunya adalah kesadaran spiritual yang dipegang oleh auditor teraktualisasi ke dalam perilaku etis editor.

Bila dikaitkan dengan hukum Islam, maka terdapat cabang ilmu yang secara rinci mempelajari mengenai ketentuan-ketentuan syariat yang dapat diterapkan pada kehidupan sehari-hari manusia yang senantiasa berinteraksi dengan Tuhan, sesama manusia dalam kehidupan sosial, ekonomi, politik, alam, dan mahluk hidup lainnya yang disebut dengan fikih. Terdapat fikih yang khusus membahas mengenai interaksi antara manusia dengan manusia lainnya adalah fikih muamalah, di mana muamalah secara spesifik sangat berkaitan dengan jual beli (Hendiana dan Aly, 2016). Sejauh ini, kebanyakan masyarakat belum memahami apa saja muamalah yang dilarang (Septyan dan Julianto, 2018).

Hukum Islam dan kaidah-kaidah fikih dalam bidang muamalah sangatlah erat kaitannya, hal ini karena kedinamisan hukum Islam yang terwujud dalam fikih sangat tergantung pada kaidah-kaidah fikih, serta keumuman dari kaidah-kaidah fikih dapat membuat 
hukum Islam mudah diterapkan pada segala situasi di setiap waktu dan tempat (Iqbal, 2018). Kaidah fikih merupakan satu disiplin ilmu yang menunjang untuk menjabarkan suatu hukum yang tak dapat ditemukan dalam nash (Sofwan, 2018).

Kaidah fikih menyederhanakan berbagai masalah dalam cabang (furu') Fikih Islam. Kaidah fikih menyelamatkan para mujtahid dari jatuh ke dalam lubang kontradiksi yang terjadi karena jika seorang mujtahid hanya terus mencari perintah atau larangan secara terpisah dalam nash tanpa menghubungkannya dengan prinsip-prinsip kolektif (Shettima et al., 2016). Lebih lanjut, Shettima et al., (2016) juga menjelaskan ini memudahkan berbagai kalangan yang bukan ahli dalam hukum Islam untuk memahami sebagian besar tema fikih tetapi melalui metodologi yang singkat.

Proses judgement auditor memutuskan suatu dilema etis selama ini hanya didasarkan oleh kode etik (Ismail et al., 2016). Pentingnya auditor menerapkan kaidah fikih muamalah dikarenakan auditor merupakan profesi yang sering berinteraksi dengan orang lain (Ardini, 2010) yang dikelilingi oleh berbagai masalah-masalah furu' yang sangat kompleks. Terkadang masalah-masalah tersebut membuat auditor mengalami permasalahan dilema etis. Kebanyakan auditor bukanlah kalangan yang memahami hukum Islam dan ilmu fikih sehingga mendapatkan kesulitan untuk mengatasi masalah dilema etis yang sesuai dengan hukum Islam (Iswanaji dan Wahyudi, 2017). Namun, kaidah fikih memudahkan auditor mengambil keputusan atau tindakan dalam masalah-masalah dilema etis.

Islam dalam fikih muamalah mengatur bagaimana seorang auditor dalam penentuan keputusan dilema etis. Kaidah-kaidah fikih muamalah diharapkan mampu memberikan kontribusi untuk menentukan keputusan dalam dilema etis seorang auditor. Maka dari itu peneliti mengajukan usulan auditor yang sesuai dengan kaidah fikih muamalah seperti: niat syarat seluruh amal seorang auditor, hukum perantara sama dengan hukum tujuan seorang auditor, hukum asal muamalah adalah halal, kecuali ada dalil yang melarang, serta hukum mendahulukan menolak mafsadat daripada mengambil manfaat agar dapat dijadikan pertimbangan auditor dalam menghadapi dilema-dilema etis.

\section{METODE PENELITIAN}

Metode penelitian yang digunakan dalam artikel ini adalah metode literature review. Hampir seluruh objek penelitian yang digunakan dalam penelitian ini berasal dari berbagai kumpulan literatur, diantaranya informasi mengenai kaidah fikih muamalah. Oleh karena itu, pendekatan yang digunakan dalam penelitian ini ialah studi kepustakaan karena metode pengumpulan data yang digunakan yaitu penelusuran data historis dari berbagai macam literatur (Bungin, 2007). Kemudian, data dan informasi yang terkumpul dalam penelitian ini merupakan fakta empirik yang dikumpulkan dengan tujuan untuk memecahkan permasalahan dan memberikan sebuah usulan bagi prinsip dasar etika profesi auditor.

Penulis terlebih dahulu mengindentifikasi prinsip-prinsip dasar etika auditor. Mengkaji berbagai literatur mengenai kaidah fikih khususnya bidang muamalah, kemudian mengidentifikasi kaidah fikih yang diharapkan dapat mengatasi permasalahan etis auditor, serta memberikan contoh-contoh praktik tidak etis auditor yang berkaitan dengan kaidah fikih muamalah yang diusulkan. Kemudian menceritakan kisah-kisah Nabi Muhammad shalallahu 'alayhi wa sallam dan para sabahat, tabi'in (orang-orang yang mengikuti sahabat), tabi'ut tabi'in (orang-orang yang mengikuti tabi'in) yang berperilaku sesuai dengan kaidah fikih muamalah yang diusulkan. Dari perbandingan antara perilaku auditor dan sahabat tersebut, penulis menyimpulkan pentingnya auditor untuk menerapkan kaidah fikih muamalah dalam pekerjaannya. Oleh karena itu, metode penelitian dengan pendekatan studi kepustakaan adalah metode yang paling sesuai untuk penelitian ini. Jenis data yang digunakan berasal dari 
sumber sekunder (Zed, 2004) yang diperoleh dari berbagai literatur dalam bentuk cetak maupun yang diterbitkan melalui mesin pencari diantaranya google ataupun situs-situs publikasi ilmiah, website resmi instansi secara online.

Selain itu, literatur berupa ayat-ayat Al-Quran beserta tafsirnya dan Al Hadits yang menjelaskan mengenai etika secara umum seperti pada QS An-Nisa' ayat 58. Kemudian, literatur berupa kode etik akuntan profesional yang telah berlaku di Indonesia penulis dapatkan melalui website resmi www.iaiglobal.or.id, kode etik akuntan profesional Internasional yang disususn oleh Federasi Akuntan Internasional penulis dapatkan melaui website resmi www.ifag.org, dan kode etik akuntan profesional yang telah sesuai dengan prinsip Islam yang penulis dapatkan melalui website www.aaoifi.com. Hal ini sesuai dengan apa yang disimpulkan oleh (Bungin, 2007: 122) bahwa data yang digunakan oleh penulis disini tidak terbatas oleh ruang dan waktu, sehingga dengan adanya data ini membuat penulis mampu mengetahui hal-hal yang pernah terjadi terkait dengan etika auditor diwaktu silam serta ternyata Islam sendiri sebelumnya telah mengeluarkan aturan etika pula melalui kitab sucinya yaitu Al-Qur'an.

\section{HASIL DAN PEMBAHASAN}

\section{Prinsip Dasar Etika Auditor}

Prinsip dasar yang wajib dimiliki oleh seorang auditor berdasarkan IAPI adalah sebagai berikut:

a. Integritas, seorang auditor wajib memiliki sikap jujur dan lugas pada segala kegiatan audit.

b. Objektivitas, seorang auditor wajib memerhatikan hal-hal yang mengandung konflik kepentingan, atau bias pertimbangan yang ditimbulkan dari pribadi atau pihak lain yang bias.

c. Kompetensi dan kehati-hatian profesional, seorang auditor wajib memerhatikan pengetahuan dan keahlian profesional sehingga jasa kepada klien harus kompeten yang sesuai dengan standar professional audit yang berlaku.

d. Kerahasiaan, seorang auditor wajib menghargai kerahasiaan informasi yang berasal dari beragam kegiatan audit seperti interaksi dengan klien maupun pihak-pihak terkait. Serta menjaga rahasia tersebut kepada pihak yang tidak berkepentingan kecuali dalam keadaan kewajiban hukum atau professional yang terikat pada auditor.

e. Perilaku Profesional, merupakan tindakan seorang auditor dalam pemenuhan kewajiban hukum dan peraturan dan juga tidak melkuakan segala tindakan yang akan berdampak terhadap kepercayaan atas profesi auditor.

\section{Kaidah-kaidah fikih muamalah pada Praktik Audit}

Dalam praktik audit, dalam kaidah-kaidah fikih muamalah ada hal yang harus diperhatikan oleh seorang auditor. Berikut adalah kaidah-kaidah fikih muamalah yang berkaitan dengan profesi auditor:

1. Niat merupakan syarat seluruh amal seorang auditor

Al-Quran melihat jual beli atau perdagangan mempunyai pengertian yang eskatologis yaitu perdagangan bukan hanya suatu aktivitas bisnis pertukaran barang atau jasa tapi juga "keyakinan, ketaatan, berinfaq, dan jihad fi sabilillah" (Fachrudin, 2017). Praktik jual beli atau muamalah sering membuat manusia lupa bahwa semua aktivitas seharusnya dikerjakan dalam rangka beribadah termasuk praktik audit. "Fikih muamalah tak lebih dari sebuah aktivitas ibadah dari rangkaian setiap jenis aktivitas hidup manusia yang berarti beraktivitas ekonomi menggunakan aturan dan prinsip Islam”. Sehingga dalam melakukan praktik audit, auditor harus meluruskan niat dalam aktivitasnya agar 
mendapatkan ridho Allah Azza wa Jalla. Niat baik dapat mencerminkan ucapan serta perbuatan. Sebaliknya, niat yang jelek mencerminkan ucapan dan amalan yang jelek (Tuasikal, 2011). Sebagaimana sabda Nabi shallallahu 'alaihi wa sallam,

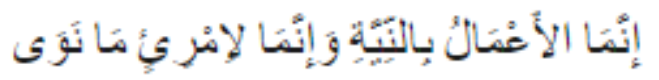

"Sesungguhnya setiap amalan tergantung pada niat. Dan setiap orang akan mendapatkan apa yang ia niatkan." (HR. Bukhari dan Muslim).

Ini adalah kaidah fikih yang komprehensif yang memiliki implikasi yang telah dibahas oleh para ulama di berbagai bidang, termasuk masalah kesalehan, transaksi komersial, dan kejahatan. Unsur niat sering mempunyai peranan dalam membedakan, misalnya, pembunuhan dari pembunuhan yang salah, pencurian dari penggunaan harta benda yang tak terbayangkan, dan kata-kata kiasan yang mungkin diucapkan oleh seorang suami untuk menyimpulkan kejadian atau perceraian (Kamali, 2003).

Pada prinsipnya semua amalan yang kita lakukan bisa dinilai ibadah, tergantung pada niat seseorang (Ulfa, 2019). Dalam suatu amalan pada diri seseorang berkumpul banyak niat. Sesuai dengan kadar niat yang dimilikinya yaitu niat yang baik, niat yang hasan, dan niat agar dapat lebih mendekatkan diri pada Allaah Subhanahu wa Ta'ala dengan ibadah bisa mendatangkan pahala, selain pahala beramal, akan mendapatkan pahala dari setiap niat yang berkumpul di dalam hatinya. Sesuai dengan fungsinya, niat ada yang berfungsi untuk membedakan antara adat (kebiasaan) dan ibadah, serta dapat membedakan satu ibadah dan ibadah lainnya (Ulfa, 2019), misalnya pekerjaan auditor yang bertujuan untuk mengaudit laporan keuangan. Ketika auditor mengalami tekanan atas permintaan klien, auditor lebih memilih mengabaikan tekanan klien yang melanggar standar audit karena takutnya pada Allah Subahanu wa Ta'ala, maka itu bisa dinilai ibadah.

Sebagai seorang auditor ketika melakukan audit atas laporan keuangan dan seluruh kegiatan perusahaan atau organisasi dituntut untuk mempunyai sifat ikhlas. Tujuan audit ialah untuk melaksanakan verifikasi bahwa subjek dari audit telah diselesaikan atau berjalan sesuai dengan standar, regulasi, dan praktik yang telah disetujui dan diterima oleh sebuah organisasi, ketika tujuan dari audit itu tidak hanya diniatkan oleh seorang auditor sebagai suatu pekerjaan, namun juga ada niat untuk mendekatkan diri pada Allah Subahanu wa Ta'ala, maka pekerjaannya bisa mendatangkan pahala. Sungguh indah anugerah Allaah Subhanahu wa Ta'ala kepada hambanya dengan dilipatgandakannya pahala suatu amalan untuk setiap niat yang baik.

Untuk memberikan penekanan yang lebih mendalam mengenai pentingnya auditor mengerti kaidah "niat syarat seluruh amal seorang auditor", maka peneliti memberikan contoh peristiwa fraud Crazy Eddie. Eddie Antar yang merupakan pemilik dari Crazy Eddie telah melakukan fraud dengan meningkatkan nilai inventori dan mencatat utang jauh lebih rendah. Fraud yang dilakukan tersebut karena Antar lengan dengan harga saham perusahaan. Auditor yang mengaudit perusahaan Crazy Eddie tidak mampu mengungkap bahwa inventori diungkapkan dengan setinggi-tingginya, namun kebalikannya, hutang dilaporkan serendahrendahnya. Hal ini tidak dapat dideteksi dikarenakan pihak ketiga yang membantu menutupi kecurangan Crazy Eddie. Auditor Crazy Eddie tidak menjaga amanah standar kode etik auditor yang telah ditetapkan, mereka telah menyalahgunakan haknya karena niatnya yang tidak baik.

Berbanding terbalik dengan kasus fraud Eddie Antar, pada masa kekhalifahan Utsman bin Affan beliau dituduh melakukan nepotisme, karena beliau menempatkan keluarga dan kerabatnya untuk menduduki jabatan-jabatan yang strategis pada masa pemerintahannya 
(Murtiningsih, 2018). Utsman bin Affan lebih mendahulukan keluarga dan kerabat-kerabatnya dari pada para sahabat yang senior, baik dari kaum Muhajirin ataupun kaum Anshar. Salah satu alasan kenapa ahli sejarah menilai Utsman bin Affan melakukan nepotisme karena beliau mengangkat Muawiyah bin Abi Sufyan yang merupakan salah satu kerabat dekat khalifah (Murtiningsih, 2018). Utsman bin Affan menjadi seorang Gubernur di daerah Syam. Namun ketika sesuatu perbuatan diawali dengan niat yang baik, maka amalannya juga akan baik. Muawiyah bin Abi Sufyan menunjukkan bahwa meskipun beliau kerabat dekat dari Khalifah Utsman bin Affan, tetapi beliau menunjukkan kinerjanya dengan maksimal dengan menunjukkan bahwa beliau menjadi gubernur Utsman bin Affan yang paling berpengaruh. Beliau dikenal dengan kecakapan dan kemampuannya untuk memimpin sebuah daerah dan berhasil membawa umat Islam pada puncak kejayaan dalam beberapa peperangan, termasuk melawan tentara Bizantium. Seharusnya seorang auditor dapat bersikap seperti Muawiyah bin Abi Sufyan dalam menjalankan tugas profesinya. Beliau menunjukkan bahwa hal-hal yang dituduhkan kepadanya bisa beliau buktikan dengan memberikan bukti bahwa kinerjanya sangat bagus yang sesuai dengan awal niat baiknya.

2. Hukum perantara sama dengan hukum tujuan seorang auditor

Dalam kaidah ini membahas tentang halal dan haram setiap aktivitas seseorang dalam menjalankan kehidupannya. Di antara cabang kaidah ini adalah bahwasanya Allah Subhanahu wa Ta'ala menyuruh agar senantiasa menyampaikan amanat kepada yang berhak menerimanya (Tuasikal, 2015) seperti pada QS An-Nisa :58

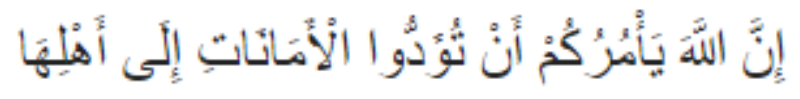

Ibnu Katsir (4: 124) menjelaskan ayat ini sebagai perintah untuk manusia agar senantiasa menyampaikan amanat kepada yang berhak. Katsir menjelaskan bahwa amanat itu adalah hak Allah Subhanahu wa Ta'ala. Termasuk di sini hak-hak yang menyangkut hambahamba Allah Subhanahu wa Ta'ala sebagian dari mereka atas sebagian yang lain, yang berhak menerimanya. Karena amanat tersebut dapat dituntut pada hari kiamat kelak. Kamali (2008) menjelaskan bahwa jika terdapat suatu yang berhukum haram maka sarana atau perantara menuju kepada hal tersebut juga menjadi haram. Namun sebaliknya jika hukum yang dimaksud wajib maka sarana atau perantara untuk melakukan perbuatan tersebut menjadi wajib. Perantara yang dimaksud sarana untuk mengantarkan atau menyampaikan sesuatu pada tujuan. Dalam hal hukum antara perantara dan tujuan Ibn al-Rifa'ah dalam (Kamali, 2008) menerangkan tergantung bentuknya yaitu: (a) suatu hal yang pasti akan menjerumuskan kepada yang haram maka hukumnya haram pula, (b) suatu hal yang jelas tidak membawa keharaman, tapi bercampur dengan suatu hal yang mendapat kepada hal yang haram maka diperlukan kehati-hatian. Hal yang harus diperhatikan adalah jika perbuatan itu jarang membawa kepada hal yang haram maka tidak perlu dilakukan penutupan sarana karena akan dipandang berlebihan, dan (c) jika sesuatu dapat menimbulkan hal yang haram dan juga dapat membawa kepada hal yang diperbolehkan, maka dpertimbangkan manfaat dan mudharatnya.

Muslim yang baik senantiasa mengimani bahwa Allah Ta'ala senantiasa memperhatikan segala ciptaanya termasuk manusia. Seorang auditor selalu mempunyai rasa takut ketika ingin melakukan hal-hal yang tidak dibenarkan yang tidak disukai Allah dan tidak menghiraukan apakah pihak lain setuju atau tidak, dan suka atau benci (Muddatstsir dan Kismawadi, 2017). Sikap ini merupakan sensor diri sehingga ia mampu bertahan terusmenerus dari godaan yang berasal dari profesi pekerjaannya (Rosyadi, 2018). Dalam melakukan pekerjaannya akuntan syariah harus bisa meyakini bahwa apapun yang 
dilakukannya selalu mendapatkan pengawasan dari Allah dan akan ia pertanggung jawabkan kelak semua apa yang telah dilakukannnya.

Saat auditor mengetahui laporan keuangan yang sedang di audit ada unsur maksiat, maka auditor berdosa juga atas pekerjaan auditornya, misal ketika auditor melakukan audit pada perusahaan dan dihadapkan pada posisi dihalangi klien dalam memperoleh bukti yang cukup dan kompeten untuk mengevaluasi ada atau tidaknya unsur pelanggaran hukum seperti fraud oleh klien yang mana telah atau nantinya memiliki dampak material terhadap hasil laporan keuangan, akan tetapi seorang auditor mengabaikan dan tidak melaporkan kejanggalan tersebut sehingga memengaruhi opini auditor menjadi tidak obyektif, akhirnya opini laporan keuangan yang diterbitkan wajar tanpa pengecualian maka itu adalah pelanggaran etika yang dilakukan oleh seorang auditor, dan termasuk kemaksiatan kepada Allaah Subhanahu wa Ta'ala karena tidak amanat. Maka seharusnya auditor menjaga independensi sehingga opini apapun yang dibuat tidak berdasarkan subyektif semata.

Profesi auditor membutuhkan seseorang yang amanah, bertanggungjawab mengungkapkan hal-hal fakta yang terjadi di lapangan (Harddiana et al., 2017). Sesuai dengan hadist Nabi Muhammad shollallahu 'alayhi wa sallam yang berpesan, "Tunaikanlah amanah kepada orang yang menitipkan amanah padamu." (HR. Abu Daud no. 3535 dan At Tirmidzi no. 1624, hasan shahih). Dengan pembahasan amanah tersebut, auditor diharapkan mampu menerapkan salah satu dari kaidah fikih muamalah sebagai kode etik seorang auditor. Untuk memberikan penekanan yang lebih mendalam mengenai pentingnya auditor mengerti kaidah "Hukum perantara sama dengan hukum tujuan seorang auditor", maka peneliti memberikan contoh peristiwa Akuntan Publik Kasner Sirumapea dan KAP Tanubrata, Sutanto, Fahmi, Bambang dan Rekan saat mengaudit PT. Garuda Indonesia yang dilaporkan oleh salah satu komisaris dari PT. Garuda Indonesia yang melakukan prosedur audit yang tidak sesuai dengan standar akuntansi yang terbukti melaporkan angka pendapatan fiktif pada Laporan Keuangan tahun 2018. Pada satu sisi, pihak yang pertama kali yang disalahkan adalah Akuntan Publik dan Kantor Akuntan Publiknya, mereka dianggap tidak kompeten memeriksa laporan audit klien. Di sisi yang lain menyalahkan PT Garuda Indonesia yang mana mereka telah membuat laporan keuangan terlebih dahulu sebelum akhirnya nanti di audit eksternal. Adanya kasus ini menunjukkan kurang amanahnya pihak-pihak yang telah diberi amanah.

Berbanding terbalik dengan kasus PT Garuda Indonesia, penulis mencoba mengaitkan dengan kisah Nabi Muhammad yang amanah. Kisah Rasulullah dan Khadijah yang diceritakan dalam Sirah Nabawiyah (Ishaq dan Hisyam, 2004: 143). Pada saat Rasulullah menjadi karyawan dari Khadijah, beliau bekerja sangat amanah. Nabi Muhammad dan Maisaroh istrinya berjualan ke Syam dengan membawa barang-barang dagangan yang telah dipercayakan oleh Khadijah untuk dijual. Sesampainya di Syam, Nabi Muhammad dan Maisaroh menawarkan dagangannya kepada para pengunjung, dan dagangannya habis laku terjual. Sebelum balik ke Mekkah, Nabi Muhammad membeli barang dagangan untuk dijual lagi di Mekkah. Sesampainya di Mekkah, Nabi jualan dan dapat keuntungan yang didapat sangat besar dan majikannya merasa puas dari penjualan tersebut. Nabi Muhammad diberikan upah yang besar sesuai dengan usahanya. Hasil dari penjualannya beliau laporkan dan serahkan semuanya kepada Maisaroh tanpa ada yang beliau potong sedikitpun. Dari kisah tersebut terlihat bahwa Nabi Muhammad sangat peduli terhadap pentingnya amanah. Seharusnya seorang auditor dapat bersikap seperti Nabi Muhammad Sholallahu 'alayhi wa sallam, beliau sangat menjaga amanah yang telah diberikan kepadanya walaupun sebenarnya selalu ada celah untuk melakukan kecurangan, akan tetapi beliau selalu menjaga amanah tersebut. 
3. Hukum asal muamalah adalah halal, kecuali ada dalil yang melarang Auditor

Menurut hukum syariah, asal hukum muamalah segala perbuatan bersifat mubah sebelum ada dalil yang menunjukkan keharamannya (Susamto, 2016), dengan kata lain, tindakan tersebut boleh dilakukan sebelum adanya dalil Al-Quran dan Al-Hadits atau fatwa ulama yang melarang.

Dalil kaidah ini adalah:

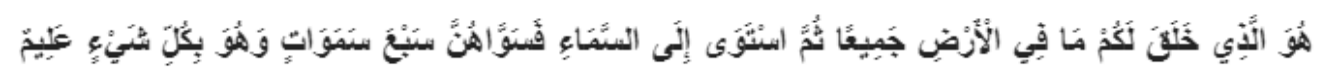

"Dia-lah Allah, yang menjadikan segala yang ada di bumi untuk kamu dan Dia berkehendak (menciptakan) langit, lalu dijadikan-Nya tujuh langit dan Dia Maha mengetahui segala sesuatu." (QS. Al Baqarah: 29)

Kaidah ini mengandung makna yang sangat besar dalam kehidupan manusia. Kaidah ini membebaskan manusia untuk melakukan segala kegiatan muamalah seperti jual-beli, bersosialisasi, berorganisasi, pendidikan, keluarga, hobi, politik, dll selama tidak terdapat dalil yang melarang. Kaidah ini secara spesifik berhubungan dengan urusan dunia manusia (Hidayatullah, 2020). Kaidah ini menjelaskan bahwa pelarangan hanya dapat dilakukan ketika terdapat dalil yang jelas mengenai pelarangannya (Permana, 2020). Ketika kita membaca dalam Al Qur'an bahwa Allah "telah menciptakan semua yang ada di bumi untuk keuntunganmu" (QS Al-Baqarah ayat 29), dan juga hadits yang menyatakan: "apa pun yang telah dibuat Allah halal adalah halal dan apa pun yang diberikan-Nya sebagai haram adalah haram, dan semua yang di atasnya Dia tetap diam diampuni ", kesimpulan dapat diambil bahwa kita diizinkan untuk menggunakan sumber daya bumi untuk keuntungan kita, dan bahwa kecuali ada sesuatu yang secara khusus dinyatakan terlarang (Kamali, 2008).

Kaidah ini pula memberikan persepsi bahwa segala ilmu ekonomi yang sudah ada bukan berarti tidak sesuai dengan Islam dan bukan pula berarti semuanya sesuai dengan ketentuan islam (Fachrudin, 2017). Jadi sebenarnya terdapat lapangan yang luas sekali dalam bidang muamalah. Manusia hanya perlu mengidentifikasi dan menghindari hal-hal yang haram. Manusia juga leluasa melakukan apa saja, dan berkreasi dalam bidang muamalah (Batubara, 2019). Hal ini juga berlaku pada masalah-masalh muamalah kontemporer. Auditor hanya perlu mengidentifikasi tindakan-tindakan yang dilarang dalam Islam. Sehingga auditor dapat melakukan inovasi dan kreativitas dalam rangka ijtihad untuk mengatasi masalahmasalah muamalah kontemporer khususnya di bidang akuntansi dan audit (Batubara, 2019).

Hukum asal perikatan auditor adalah boleh (mubah), namun menjadi haram ketika terdapat praktik-praktik yang diharamkan dalam Islam, seperti riba, gharar, dan maytsir. Riba, dalam praktik ini contohnya ketika memeriksa laporan keuangan sebuah perusahaan/organisasi, dilihat kebenaran transaksinya, misalnya ada pinjaman yang ada suku bunga, salah satu tugas auditor adalah melihat dicatat atau tidaknya bunga. Ketika memeriksa benar atau tidaknya dibayarkan bunga, bunganya dihitung maka seorang auditor itu berdosa. Dalam Islam suku bunga bank dikenal sebagai Riba, riba hukumnya haram, tidak boleh dibayarkan. Maka sebaiknya ketika melakukan perikatan audit, seorang auditor Muslim harus menyebutkan bahwa dia tidak boleh menyentuh area riba.

Kasus SNP Finance terjadi karena perikatan audit (audit engagement) yang cukup lama. Hal ini tentu menimbulkan resiko yang besar yaitu kedekatan antara auditor dan klien sehingga menyebabkan kurangnya independensi dan sikap skeptisme auditor. Kasus Enron juga merupakan hasil dari perikatan audit yang dapat membuka celah untuk melakukan pemufakatan dalam melakukan tindak kejahatan. Kedua kasus diatas merupakan kurang jelasnya dan praktik gharar dalam ruang lingkup audit dan batasan hubungan antara auditor dengan klien. Batasan ruang lingkup audit juga bertujuan untuk mencegah pemufakatan 
kejahatan auditor dan klien serta berfungsi untuk meningkatkan independensi dan skeptisme auditor. Perikatan audit harus terlepas dari prkatik gharar (ketidakjelasan). Perikatan audit harus dapat menjelaskan tujuan, tanggung jawab dan pembatasan tanggung jawab, ruang lingkup, dan akses auditor. Sehingga, auditor maupun klien dapat melakukan transaksi muamalah sesuai dengan hak dan kewajibannya. Perikatan audit yang jelas juga mampu memberikan perlindungan terhadap audit atas tindakan kejahatan atau fraud yang dilakukan oleh klien. Dalam suatu perikatan, auditor juga dapat menilai resiko atas perikatan audit. Hal ini tentu menjadi pertimbangan fee audit. Namun lebih jauh, penliaian resiko juga bertujuan untuk menentukan keputusan menerima atau menolak perikatan audit. Keberadaan hak memilih (khiyar) dalam perikatan dapat membantu auditor terhindar dari kemudharatan atas perikatan audit yang beresiko menimbulkan praktik-praktik yang diharamkan oleh Islam.

4. Hukum mendahulukan menolak mafsadat daripada mengambil manfaat

Dalam kaidah ini lebih baik menolak mafsadat daripada mengambil manfaat. Firman Allah:

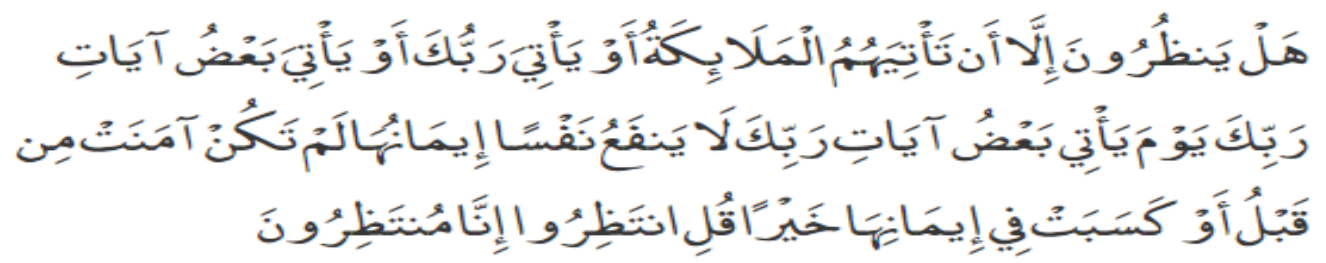

"Dan janganlah kamu memaki sembahan-sembahan yang mereka sembah selain Allah, karena mereka nanti akan memaki Allah dengan melampaui batas tanpa pengetahuan. Demikianlah Kami jadikan setiap umat menganggap baik pekerjaan mereka. Kemudian kepada Tuhan merekalah kembali mereka, lalu Dia memberitakan kepada mereka apa yang dahulu mereka kerjakan". (Al-An'am: 108)

Dalam tafsir Ibnu Katsir beliau menjelaskan ayat ini turun untuk melarang Rasul-Nya dan kaum mukminin untuk menghina sembahan-sembahan selain Allah Subhanahu wa Ta'ala dan hanya pada Tuhan merekalah kembali mereka. Ayat ini dijelaskan oleh Ibnu katsir bahwa meskipun terdapat maslahat dalam celaan tersebut, namun juga terkadung mafsadat (kerusakan) yang lebih besar daripada itu. Ibnu kasir menjelaskan kerusakan adalah balasan kaum kafir atas celaan kamum muslimin.

Kaidah ini merupakan perintah dan larangan antara hal yang dapat meimbulkan baik maslahat dan mafsadat. Kaidah ini berisi mengenai pertimbangan dalam suatu hal yaitu saat masalahat hilang atau menimbulkan mafsadat yang lebih banyak, maka janganlah melakukan hal tersebut (Aprillia et al., 2018). Bahkan menjadi haram ketika menimbulkan mafsadat yang lebih besar dan mendapatkan sedikit maslahat (Hakim dan Irawan, 2019).

Kaidah ini menganjurkan agar auditor lebih mengutamakan untuk menghindari atau tidak menjalakan prosedur-prosedur audit yang menimbulkan mudharat yang besar meskipun dapat menciptakan mafaat yang sama besarnya. Syaikhul Islam juga menjelaskan secara rinci bahwa pertimbangan atas maslahat dan mafsadat haruslah sesuai syariat. Sehingga jika terdapat hal-hal yang berisi ma'ruf dan mungkar, dan tidak bisa memisahkan antara keduanya, bahkan mengerjakan semuanya atau meninggalkan semuanya, maka tidak boleh memerintahkan mengamalkan hal ma'ruf atau mencegah kemungkaran kecuali setelah melakukan kajian atas permasalahan tersebut (Sa'id, 2014). Manusia memiliki beragam pilihan hidup termasuk menjadi akuntan. Akuntan diberi pilihan untuk taat Syariat atau tidak. Akuntansi syariah yang telah berkembang menjadi alternatif bagi seorang calon akuntan sebagai sebuah lahan pekerjaan yang memilki keunikan (Muddatstsir dan Kismawadi, 2017).

Untuk memberikan penekanan yang lebih mendalam mengenai pentingnya auditor mengerti kaidah "mendahulukan menolak mafsadat daripada mengambil manfaat", maka 
peneliti memberikan contoh peristiwa "Fraud Crazy Eddie". Dapat diketahui secara luas, bahwa auditor yang menjadi pemeriksa perusahaan milik Eddie Antar ini adalah auditor muda milik Peat Marwick Main (PMM) yang nantinya lebih dikenal dengan KPMG. Auditor yang menangani Crazy Eddie adalah beberapa auditor muda dan masih kurang berpengalaman yang baru lulus kuliah. Para auditor muda tersebut juga hanya di supervisi oleh senior auditor yang hanya lebih tua beberapa tahun dengan mereka. Para auditor tersebut diketahui tidak melakukan uji pengendalian (test of control) terhadap Crazy Eddie, walaupun mereka tahu bahwa perusahaan tersebut memiliki pengendalian internal yang jelek. Tidak dilakukkannya pengujian tersebut dikarenakan para auditor lebih memilih untuk mempercayai perkataan dari karyawan Crazy Eddie, yang memang ditugaskan oleh atasan mereka untuk memengaruhi penilaian auditor terhadap perusahaan.

Auditor PMM juga tidak melakukan pengujian terhadap laporan kuartal Crazy Eddie, hal tersebut dikarenakan auditor lebih terfokus pada pemeriksaan laporan tahunan secara keseluruhan dan juga karena waktu audit yang tidak terlalu lama. Selama waktu audit, eddie antar memberikan perintah kepada karyawannya untuk "mendekati" para auditor muda PMM, dan efek yang terjadi adalah terbaginya fokus auditor untuk melakukan proses audit, dengan "meladeni" karyawan Crazy Eddie tersebut. Dengan adanya fokus yang terbagi dan juga waktu audit yang singkat, maka auditor tidak melakukan pengujian yang seharusnya dilakukan saat proses audit berlangsung. Adanya kedekatan berlebihan antara auditor dengan klien membuat penilaian mereka tidak objektif. Kedekatan yang berlebihan terbukti membuat auditor terlalu percaya dengan apa yang dikatakan oleh kliennya, sehingga tidak memeriksa secara detil apa yang sesungguhnya terjadi. Karena kelalaian auditor untuk memberikan penilaian secara objektif itulah yang membuat fraud Crazy Eddie berjalan mulus, sehingga merugikan para pemegang saham hingga total kerugian sebesar lebih dari \$100 juta.

Berbanding terbalik jika "mendahulukan menolak mafsadat daripada mengambil manfaat". Kisah seorang hakim pada masa kekhalifaan Ali bin Abi Thalib, yang membuat keputusan merugikan bagi beliau (Hafiz, 2015). Dikisahkan pada suatu hari beliau sedang berjalan melewati rumah-rumah penduduk Madinah, di tengah perjalanannya, beliau melihat baju zirah beliau yang sebelumnya hilang dicuri oleh orang lain berada di rumah kafir yahudi. Tidak lama setelah melihat baju zirah tersebut, Beliau mengajak orang yahudi itu ke pengadilan untuk membuktikan kepemilikan atas baju zirah tersebut. Dalam hukum pengadilan Islam, dibutuhkan minimal dua orang saksi laki-laki atau dua orang perempuan untuk menggantikan satu orang saksi laki-laki.

Peraturan Islam juga menyebutkan bahwa anak kandung tidak bisa dijadikan saksi penguat dalam pengadilan (Hafiz, 2015). Saat pengadilan berlangsung Ali bin Abi Thalib hanya bisa membawa satu saksi perempuan, sehingga hakim Syuraih yang saat itu memimpin persidangan masih mewajibkan beliau untuk membawa lagi tiga orang saksi perempuan. Karena beliau tidak mampu menghadirkan saksi tambahan, baju zirah yang seharusnya milik beliau diputuskan oleh hakim menjadi milik orang kafir yahudi. Ali bin Abi Thalib adalah seorang khalifah yang menunjuk Syuraih untuk menjadi hakim, seorang sepupu nabi Muhammad Shalallahu 'alayhi wasallam, dan seseorang yang di didik secara pribadi oleh nabi Muhammad Shalallahu 'alayhi wasallam, namun argumen beliau tetap kalah di mata hakim Syuraih, karena tidak sesuai dengan pedoman dalam pengadilan yang seharusnya. Dalam kisah tersebut hakim Syuraih lebih memilih untuk menaati aturan hukum dalam Islam dibanding mengikuti pendapat dari Beliau, terlepas dari kedekatan hakim Syuraih dengan Beliau. Seharusnya seorang auditor dapat bersikap seperti hakim syuraih dalam membuat keputusan. Keputusan yang dibuat secara objektif pasti akan selalu membawa manfaat yang baik di masa mendatang, kepada orang banyak. Keputusan auditor yang objektif juga dapat mencegah timbulnya hal yang merugikan di masa mendatang, terlepas dari efek atau imbas yang ditimbulkan oleh keputusan auditor pada masa kini. 


\section{PENUTUP}

Dengan pembahasan kaidah-kaidah fikih muamalah tersebut jika itu diterapkan maka diharapkan seorang auditor dalam menentukan sikap bisa mempertimbangkan atau bahkan kaidah fikih muamalah dapat berkontribusi dalam penentuan keputusan dilema etis, auditor bisa bekerja secara objektif dan lebih dipercaya oleh klien dan masyarakat publik yang membaca laporan keuangan dari perusahaan klien. Esensi perihal etis sangat penting dalam akuntansi terutama dalam rangka pengembangan dan peningkatan peran profesi akuntan untuk dapat bertindak secara profesional.

Auditor dalam melakukan profesinya sangatlah erat kaitannya dengan individu lainnya. Dalam Islam, interaksi antar manusia diatur dalam fikih muamalah. Penentuan hukum fikih muamalah harus didasarkan pada kaidah-kaidah fikih muamalah yang sudah mapan. Dalam kaitannya dengan auditor, kaidah fikih muamalah dapat memberikan alat bantu bagi auditor untuk memutuskan persoalan-persoalan etis. Karena auditor memisahkan agama dengan pekerjaan, maka mereka tidak memiliki prinsip dalam bekerja, sehingga mereka sering terkena dilema etis. Auditor yang tidak menerapkan kaidah fikih muamalah cenderung kinerjanya mengarah ke hal-hal yang kurang baik setelah dibandingkan dengan kisah para sahabat nabi, tabi'in, tabi'ut tabi'in yang menerapkan kaidah fikih muamalah. Auditor seharusnya menerapkan kaidah fikih muamalah dalam pekerjaannya sebagai akuntan publik, karena fikih muamalah mengajarkan seluruh kegiatan yang berhubungan dengan muamalah manusia yang sesuai dengan perintah dan larangan dari Allah Subhanahu wa Ta'ala beserta dengan hukum-hukum Islam yang sudah ditetapkan seperti wajib, sunnah, mubah, makruh, dan haram.

Penelitian ini memiliki keterbatasan yaitu penelitian hanya menggunakan satu sumber data yaitu literature review. Sehingga penelitian selajutnya diharapkan dapat menggunakan sumber data yang lainnya seperti observasi dan wawancara. Penelitian selanjutnya diharapkan dapat menggali kaidah-kaidah fikih muamalah yang lain yang dapat diterapkan dalam praktik audit. 


\section{DAFTAR PUSTAKA}

Alim, M. N., Hapsari, T., \& Purwanti, L. (2007). Pengaruh kompetensi dan independensi terhadap kualitas audit dengan etika auditor sebagai variabel moderasi. Simposium Nasional Akuntansi X, 26-28.

Aprillia, Q. D., Nurhasanah, N., \& Ibrahim, M. A. (2018). Implementasi Kaidah Maslahah Mursalah Akad Qardhul Hasan untuk Produk Tabungan di Perbankan Syariah. Prosiding Hukum Ekonomi Syariah, 483-488.

Ardini, L. (2010). Pengaruh Kompetensi, Independensi, Akuntabilitas dan Motivasi Terhadap Kualitas Audit. Jurnal Ekonomi Dan Bisnis Airlangga (JEBA)| Journal of Economics and Business Airlangga, 20(3).

Batubara, Z. (2019). Akuntansi Dalam Pandangan Islam. JAS (Jurnal Akuntansi Syariah), $3(1), 66-77$.

Bungin, H. . B. (2007). Penelitian Kualitatif: komunikasi, ekonomi, kebijakan publik, dan ilmu sosial lainnya. Retrieved November 13, 2019, from Jakarta: Kencana Prenada Media Group website: http://elibrary.dephub.go.id/opac/detail-opac?id=3192

Fachrudin, F. (2017). Filosofi Laba Dalam Perspektif Fiqh Mu'amalah Dan Ekonomi Konvensional. Al-Mashlahah: Jurnal Hukum Islam Dan Pranata Sosial Islam, 3(06). https://doi.org/10.30868/AM.V3I06.146

Futri, P. S., \& Juliarsa, G. (2014). Pengaruh Independensi, Profesionalisme, Tingkat Pendidikan, Etika Profesi, Pengalaman, dan Kepuasan Kerja Auditor Pada Kualitas Audit Kantor Akuntan Publik di Bali. E-Jurnal Akuntansi.

Hafiz, A. (2015). Perkembangan Awal Peradilan Islam (Studi Tentang Penerapan PrinsipPrinsip Negara Hukum). Nuansa, 8(2).

Hakim, R., \& Irawan, M. D. (2019). Islamic Rulings and Financial Technology (Fintech): An Analysis on the Relevance and Implications. MADANIA: JURNAL KAJIAN KEISLAMAN, 23(2), 137-146.

Harddiana, R., Triyuwonob, I., \& Mulawarman, A. D. (2017). Biografi Umar bin Khattab RA: Sebuah Analogi bagi Independensi Auditor. Retrieved November 13, 2019, from Jurnal Ekonomi, Manajemen, dan Akuntansi Islam website: http://jurnal.fordebi.or.id/index.php/home/article/view/27/23

Hendiana, R., \& Aly, A. D. (2016). Transaksi Jual Beli Online Perspektif Ekonomi Islam. AlMustashfa: Jurnal Penelitian Hukum Ekonomi Syariah, 3(2).

Herawaty, A., \& Susanto, Y. K. (2010). Pengaruh Profesionalisme, Pengetahuan Mendeteksi Kekeliruan, dan Etika Profesi Terhadap Pertimbangan Tingkat Materialitas Akuntan Publik. Jurnal Akuntansi Dan Keuangan, 11(1), 13-20.

Hidayatullah, M. S. (2020). Pemaknaan Kaidah Fikih "ar-Ridhâ Bisy SyaiRidhâ bimâ Yatawalladu Minhu" dalam Ekonomi Syariah. TAFAQQUH: Jurnal Hukum Ekonomi Syariah Dan Ahwal Syahsiyah, 5(1), 69-80.

Iqbal, M. (2018). Urgensi Kaidah-Kaidah Fikih Terhadap Reaktualisasi Hukum Islam Kontemporer. EduTech: Jurnal Ilmu Pendidikan Dan Ilmu Sosial, 4(2).

Ishaq, I., \& Hisyam, I. (2004). Sirah Nabawiyah Ibnu Hisyam Jilid 1. Fadhli Bahri Bekasi. Darul Falah: Jakarta.

Ismail, A. H., Iskandar, T. M., Sanusi, Z. M., \& Shukor, Z. A. (2016). auDitor's ethical JuDgements: assessing the effect of ethical sensitivity anD ethical climate. Management \& Accounting Review (MAR), 15(2), 185-207.

Iswanaji, C., \& Wahyudi, M. (2017). Formalitas Fikih dalam Penerapan Akuntansi Syariah Aliran Pragmatis. Jurnal Akuntansi Multiparadigma, 8(3), 583-599.

Kamali, M. H. (2003). Principles of Islamic Jurisprudence (Islamic Texts Society). Cambrige, 3rd Revise(1/2), 338. https://doi.org/10.2307/1051529 
Kamali, Mohammad Hashim. (2008). Qawa 'id al-fiqh: The legal maxims of Islamic law. The Association of Muslim Lawyers.

Katsir, I. (n.d.). Tafsir Al-Qur'an Al-'Azhim (I). Dar Ibnul Jauzi.

Khoriyah, S. L. (2013). Analisis Faktor Personal dan Pertimbangan Etis Terhadap Perilaku Auditor pada Situasi Konflik Audit. Accounting Analysis Journal, 2(4).

Muddatstsir, U. D. Al, \& Kismawadi, E. R. (2017). Akuntan Syariah Di Era Modern, Urgent Kah Di Indonesia? Ihtiyath: Jurnal Manajemen Keuangan Syariah, 1(1). https://doi.org/10.32505/IHTIYATH.V1I1.675

Murtiningsih, M. (2018). Tuduhan Nepotisme Terhadap Utsman Bin Affan Dan Pengaruhnya Terhadap Kekhalifahan Ali Bin Abi Thalib. Jurnal Ilmu Agama: Mengkaji Doktrin, Pemikiran, Dan Fenomena Agama, 19(1).

Nichols, D. R., \& Price, K. H. (1976). The auditor-firm conflict: an analysis using concepts of exchange theory. The Accounting Review, 51(2), 335-346.

Noviriani, E., Ludigdo, U., \& Baridwan, Z. (2018). Studi Fenomenologi Atas Dilema Etis Auditor Internal Pemerintah. EKUITAS (Jurnal Ekonomi Dan Keuangan), 19(2), 217240.

Permana, I. (2020). Penerapan Kaidah-Kaidah Fiqih Dalam Transaksi Ekonomi Di Lembaga Keuangan Syariah. Tahkim (Jurnal Peradaban Dan Hukum Islam), 3(1).

Rosyadi, I. (2018). Penggunaan Kaidah Fikih Dalam Fatwa Majelis Ulama Indonesia Tentang Keuangan Syariah. Al-Daulah: Jurnal Hukum Dan Perundangan Islam, 8(02), 425-453.

Sa'id, U. (2014). Kaidah Penting: Menolak Mafsadat Didahulukan daripada Mengambil Manfaat. Retrieved November 13, 2019, from Muslimah.Or.Id website: https://muslimah.or.id/5148-kaidah-penting-menolak-mafsadat-didahulukan-daripadamengambil-manfaat.html

Septyan, K., \& Julianto, W. (2018). Model Pembelajaran Syariah di Jurusan Akuntansi. Jurnal Pendidikan Ekonomi Dan Bisnis (JPEB), 6(1), 15-24.

Shettima, M., Biu, H. A., \& Deribe, M. A.-A. (2016). The Relevance of Islamic Legal Maxims in Determining Contemporary Legal Issues. IIUM Law Journal.

Singgih, E. M., \& Bawono, I. R. (2010). Pengaruh Independensi, Pengalaman, Due Professional Care dan Akuntabilitas Terhadap Kualitas Audit. Simposium Nasional Akuntansi XIII, 1-21.

Sofwan, A. (2018). Interelasi Qowaid Usul Dan Fiqhiyah Sebagai Sebagai Landasan Hukum Islam Yang Universal. Legitima: Jurnal Hukum Keluarga Islam, 1(1), 1-19. https://doi.org/10.33367/legitima.v1i1.640

Susamto, B. (2016). Tingkat Penggunaan Multi Akad Dalam Fatwa Dewan Syari'ah Nasional-Majelis Ulama Indonesia (DSN-MUI). Retrieved November 13, 2019, from Al-Ihkam: Jurnal Hukum dan Pranata Sosial website: http://www.ejournal.stainpamekasan.ac.id/index.php/alihkam/article/view/862/737

Tjun, L. T., Marpaung, E. I., \& Setiawan, S. (2013). Pengaruh kompetensi dan independensi auditor terhadap kualitas audit. Jurnal Akuntansi Maranatha, 4(1), 33-56.

Tsui, J. S. L., \& Gul, F. A. (1996). Auditors' behaviour in an audit conflict situation: A research note on the role of locus of control and ethical reasoning. Accounting, Organizations and Society, 21(1), 41-51.

Tuasikal, M. A. (2011). Kaedah Fikih (1), Niat Syarat Seluruh Amal. Retrieved November 13, 2019, from Rumaysho.com website: https://rumaysho.com/1548-kaedah-fiqhiyah-1-niatsyarat-seluruh-amal.html

Tuasikal, M. A. (2015). Kaedah Fikih (18): Hukum Perantara Sama dengan Hukum Tujuan. Retrieved November 13, 2019, from Rumaysho.com website: https://rumaysho.com/10130-kaedah-fikih-18-hukum-perantara-sama-dengan-hukumtujuan.html 
KODE ETIK AKUNTAN PUBLIK DALAM KAIDAH FIKIH MUAMALAH

Astuti Dola Bastina, Tjiptohadi Sawarjuwono dan Gemelthree Ardiatus Subekti

Ulfa, H. (2019). Kaidah Fiqh Bidang Mu'amalah Mazhab Syafi'i (Kajian Teoritis dan Praktik serta Kehujjahannya). JURNAL IQTISAD, 6(1), 32-49.

Zed, M. (2004). Metode Penelitian Kepustakaan. Retrieved November 13, 2019, from Yayasan Pustaka

Obor

Indonesia website: https://books.google.co.id/books/about/Metode_Penelitian_Kepustakaan.html?hl=id\&id= zG9sDAAAQBAJ\&redir_esc=y. 